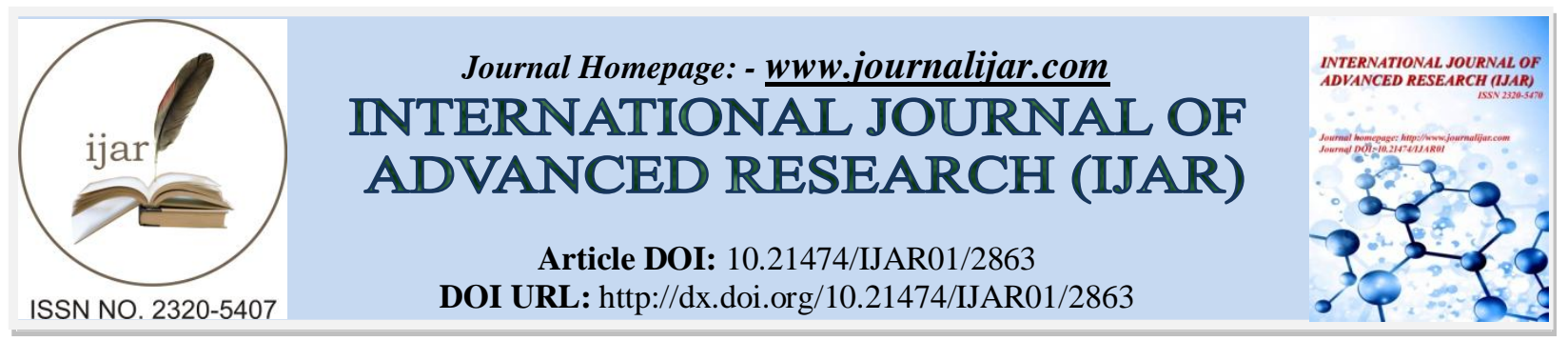

RESEARCH ARTICLE

\title{
STRUCTURAL VALIDATION AND HOMOLOGY MODELING OF DIFFERENTIALLY EXPRESSED PROTEINS IN RATTUS NORVERGICUS INDUCED BY BISPHENOL A AND PROBIOTIC TREATEMENT
}

\author{
Ms. S. Preethi ${ }^{1}$ and Dr. J. Pramoda Kumari ${ }^{2}$. \\ 1. Department of Microbiology, S.V. University, Tirupati-517 502, Andhra Pradesh, India. \\ 2. Assistant Professor, Department of Microbiology, S.V.University, Tirupati-517 502, Andhra Pradesh, India.
}

\section{Manuscript Info}

\section{Manuscript History}

Received: 21 November 2016

Final Accepted: 21 December 2016

Published: January 2017

Key words:-

Homology Modeling, Bioinformatics,

Bisphenol stressed, Bisphenol and probiotic treated proteins.

\section{Abstract}

\begin{abstract}
The aim of the present study was to apply Bio informatics tools to the proteins expressed in alteration with Bisphenol A. The structure-based computational methods are needed to help, identify and characterize protein-protein complexes and their function. Differentially expressed Proteins were Tryptic digested and were analyzed by MALDI-TOF to identify peptide masses afterward used for MS/MS. For individual proteins, the most successful technique is homology modeling. Based on their mass to charge ratio, the expressed proteins sequences were collected from Mascot search data. The sequences were analysed with the help of Phyre-2 server, RasMol version 2.6 software, BLAST, QMEAN servers, SWISS-PROT, QMEAN servers, STRING and Rampage validation tool.
\end{abstract}

Copy Right, IJAR, 2016,. All rights reserved.

\section{Introduction:-}

Bioinformatics is the discipline of science in which biology, computer science, and information technology merge to form a single command. A web server for the analysis and comparison of 2D gels using bioinformatics tools has been developed, [1]. Functional analysis and elucidation of large-scale proteomics and gene expression data require effective use of bioinformatics tools and collective information resources coupled with expert-guided examination [2]. Bisphenol-A (BPA), one of many environmental endocrine disrupters, is widely used in polycarbonate plastics, food cans and dental sealants. It is generally believed that consumer exposure to BPA occurs primarily via food in contact with BPA-containing materials, such as polycarbonate baby bottles, table ware and food containers as well as food and beverage cans lined with epoxy resins. Differences in the estrogenic activity of bisphenol A and reference estrogens may be due to differences in recruiting by the liganded receptor of co-regulatory proteins. BPA is thought to bind to plasma proteins in rodents, monkeys and humans [3]. Because pharmacokinetics are altered by protein binding, the potential uptake of BPA into other tissues, including estrogen-target tissues, may be affected. In proteomics ground, combinations of analytical techniques are used to analyse the protein samples. The initial step in all proteomic studies involves the separation of a mixture of proteins. This can be conceded out using 2-D gel electrophoresis technique in which proteins are separated based on their individual molecular weight and charges. Two dimensional gel electrophoresis can retrieve information regarding thousands of different proteins from a crude protein sample. The spots obtained in 2-D gel electrophoresis are separated and subjected to mass spectrometric analysis using MALDI-TOF. MALDI-TOFMS/MS data converted into MGF (Mascot Generic Format). This data can be analysed by using MASCOT server. Mascot is widely used by research facilities around the world. Mascot uses a probabilistic scoring algorithm for protein identification that was adapted from the MOWSE algorithm. 
Mascot is a software search engine that uses mass spectrometry data to identify proteins from peptide sequence databases [4]. This sequence is aligned by using alignment tools, sequence alignment is to identify the functional and structural relationship between the sequences [5].The first step in comparative modelling is to distinguish all protein structures related to the target sequence, some of which will be used as templates. This step is greatly facilitated by databases of protein sequences and structures and software for scanning those databases. The target sequence can be searched against sequence databases, such as Protein Identification Resource (PIR), GENBANK , SWISS-PROT, or EMBO nucleotide sequences database, and/or structure databases such as the Brookhaven Protein Databank and SCOP. The most popular programs, including FASTA and BLAST to compare the target sequence with each sequence in a database Program MODELLER which implements all the stages in comparative modelling [6], can also automatically search for proteins with known three-dimensional structure that are related to a given sequence. QMEAN is a composite scoring function which is able to derive both entire structure and residue of protein error estimates on the basis of one single model $[7,8]$.

\section{Experimental:-}

Tissue collection:-

The hippocampal regions of the brain were dissected and then stored at $-80^{\circ} \mathrm{C}$ until use. The tissue was homogenized on ice with a cold Tris/EDTA buffer and centrifuged at $10,000 \mathrm{~g}$ for $20 \mathrm{~min}$ at $48^{\circ} \mathrm{C}$. Supernatant was collected and processed for protein analysis. [9] About $0.5 \mathrm{~g}$ of each liver was homogenized in $4.5 \mathrm{ml}$ of phosphate buffered saline.The crude tissue was centrifuged at $8000 \mathrm{~g}$ for $30 \mathrm{~min}$ and the supernatant was collected and stored at $4^{\circ} \mathrm{C}$ [10]

\section{D gel electrophoresis:-}

The samples were loaded on to the IEF strips $3-10 \mathrm{pH}$ Linear, $18 \mathrm{~cm}$ and kept for Iso-Electric Focusing. After IEF run, the strip was equilibrated in Equilibration Buffer and the second dimension was carried out on a 10\% SDSPAGE. The gels were Silver stained to observe the protein spots and were scanned using Epson Expression 11000XL Scanner

\section{MS Analysis:-}

Mass spectrometry is an important emerging method (Model voyager De-STR, applied Biosystems, Foster, CA, USA) for the characterization of proteins from isolated 2-D gel spots as this method is very sensitive. Spot was treated with acetonitrile for dehydration and trypsin for protein digestion. $\alpha$-cyano-4-hydroxycinnamic acid in acetonitrile was used as matrix.

\section{MASCOT Search:-}

After MALDI-TOF MS/MS analysis expressed protein data is converted into MGF (MascotGeneric Format). These data can be analysed by using MASCOT server(http://www.matrixscience.com). Mascot has three main search modes: Peptide MassFingerprint, Sequence Query, and MS/MS Ion Search. MS/MS Ion Search is used to analyse data from tandem mass spectrometry experiments. The report was generated depending on specific options used for protein analysis. For each protein match, Mascot calculates an overall Protein Score. This number reflects the combined scores of all observed mass spectra that can be matched to amino acid sequences within that protein. A higher score indicates a more confident match. The number of protein matches at each scoring position is indicated by the height of the red bars, the non-significant area is shaded in green. Complete results are automatically sent to the registered E-mail.

\section{Sequence alignment:-}

The target sequence was searched with BLAST search against Protein Data Bank, which one has a high level of sequence identity with target protein selected as a template protein. Templates were determined by super imposition of the two structures and multiple sequence alignment was performed with CLUSTAL W (11) program to identify the set of conserved residues alignment.

\section{Homology modeling:-}

The sequences were analysed with the help of Phyre-2 (protein Homology/analogy Recognition Engine V 2.0) server for obtaining pdb file. The final 3-D structure obtained with the help of RasMol version 2.6 software programme. 


\section{Ramachandran plot analysis:-}

Ramachandran plot displays the phi and psi backbone conformational angles for each residue in a protein. The phi angle is the angle of right-handed rotation around $\mathrm{N}-\mathrm{C} \alpha$ bond and the psi angle is the angle of right-handed rotation around $\mathrm{C} \alpha-\mathrm{C}$ bond. Phi and psi angles are also used in the classification of some secondary structure elements such as alpha helix and beta turns. In a Ramachandran plot, the core or allowed regions indicate preferred areas for psi/phi angle pairs for all residues in a protein. If the determination of protein structure is reliable, most pairs will be in the favoured regions of the plot, some pairs will be in the allowed region, and only a few will appear in 'disallowed' regions

\section{QMEAN analysis for the quality resolution structure:-}

The QMEAN scoring function estimates the global quality of the models on the basis of a linear combination of six structural descriptions, four of them are statistical potentials of mean force. The local geometry is analysed by a torsion angle potential over three consecutive amino acids. The distance -dependent interaction potentials based on $\mathrm{C} \beta$ atoms and all atoms, respectively are used to assess long-range interactions. A solvation potential describes the burial status of the residues. The analysis of these Z-scores of the individual terms can help identifying the geometrical features responsible for an observed large negative QMEAN Z-score. Models of low quality are expected to have strongly negative Z-scores for QMEAN but also for most of the contributing terms. Large negative values correspond to red regions in the colour gradient. Good structures are expected to have all sliders in the light red to blue region. The quality of resolution structure of differentially expressed proteins under control, bisphenol and bisphenol with probiotic treated samples represented in the following figures

\section{Analysis of physico-chemical parameters of a sequence:-}

Protparam is one among the protein analysis tool available on the ExPasy server. (http://www.expasy.org/tools/protparam.html).It is used for calculating various physiochemical parameters of a provided protein. The protein can be either is specified as a UniProtKB/Swiss-Prot accession number or ID or as sequences of amino acids.

\section{String analysis of differentially expressed proteins:-}

The database STRING is a precomputed global resource for the exploration and analysis of these associations. Since the three types of evidence differ conceptually, and the number of predicted interactions is very large, it is essential to be able to assess and compare the significance of individual predictions. Protein-protein interactions are not limited to direct physical binding. Proteins may also interact indirectly by sharing a substrate in a metabolic pathway, by regulating each other transcriptionally, or by participating in larger multi-protein assemblies. For information on genomes, genes, and encoded proteins, STRING relies on the annotated proteomes maintained bySWISS-PROT.

\section{Results:-}

Table 1:- List of differentially expressed proteins of hypothalamus tissue of Rattus norvergicus in response to BPA and BPA with probiotic treatement.

\begin{tabular}{|l|l|l|l|l|}
\hline Spot no & Protein name & Molecular weight & Calculated pI & $\begin{array}{l}\text { Number of } \\
\text { amino acids }\end{array}$ \\
\hline BH3 & $\begin{array}{l}\text { gamma-actin, partial } \\
\text { [Musmusculus] }\end{array}$ & 41018.9 & 5.56 & 268 \\
\hline BH4 & $\begin{array}{l}\text { Protein transport protein } \\
\text { Sec31A }\end{array}$ & 133569.2 & 6.30 & 1230 \\
\hline BH5 & $\begin{array}{l}\text { Atp5b protein } \\
\text { [Musmusculus] }\end{array}$ & 56666.8 & 5.24 & 533 \\
\hline BPH3 & $\begin{array}{l}\text { PREDICTED: } \\
\text { polyadenylate-binding } \\
\text { protein 4 isoform X3 }\end{array}$ & 69331.3 & 9.58 & 630 \\
\hline BPH4 & $\begin{array}{l}\text { V-type proton ATPase } \\
\text { catalytic subunit A 68326.0 }\end{array}$ & 5.41 & 617 \\
\hline
\end{tabular}


Table 2:- List of differentially expressed proteins in liver tissue of Rattus novegicus in response to BPA and BPA with probiotic treatement

\begin{tabular}{|l|l|l|l|l|}
\hline Spot no & Protein name & $\begin{array}{l}\text { Molecular } \\
\text { weight }\end{array}$ & Calculated pI & Number of Amino acids \\
\hline BL1384 & $\begin{array}{l}\text { INSL3_MOUSE, Insulin-like } \\
3\end{array}$ & 13585.8 & 9.25 & 122 \\
\hline BL1500 & $\begin{array}{l}\text { ATP synthase subunit beta, } \\
\text { mitochondrial precursor } \\
\text { [Musmusculus] }\end{array}$ & 56300.4 & 5.19 & 529 \\
\hline BL1549 & $\begin{array}{l}\text { Laminin subunit alpha-5 } \\
\text { precursor }\end{array}$ & 404053.6 & 6.28 & 3718 \\
\hline BPL119 & Nucleolar protein 14 & 98769.4 & 7.34 & 860 \\
\hline BPL128 & Nuclear protein MDM1 & 75673.7 & 9.33 & 673 \\
\hline
\end{tabular}

a) gamma-actin, partial [Musmusculus] target protein (3ub5 selected as a reference structure for modeling of BH3- gamma-actin, partial [Musmusculus])

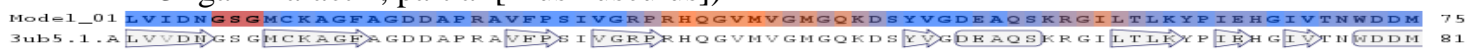

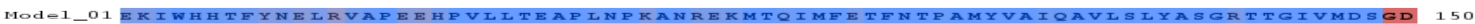

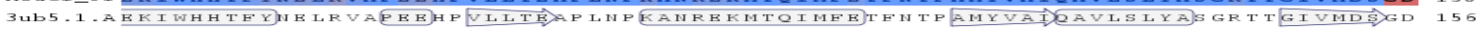

MOdE1_01 GVTHTVPIXEGYALPHAILRDIAGRDITDYLMKIITEREYSFTTTAEREIVRDIKEKLCYVALDFEOEMATAAS 225

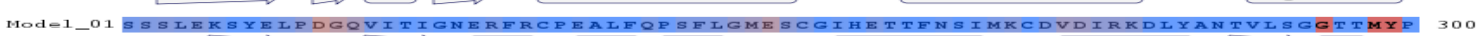

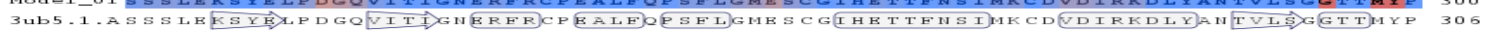

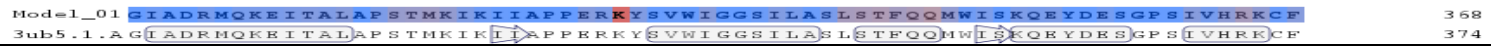

b) Protein transport protein Sec31A target protein (4bzj selected as a reference structure for modeling of BH4- Protein transport protein Sec31A)

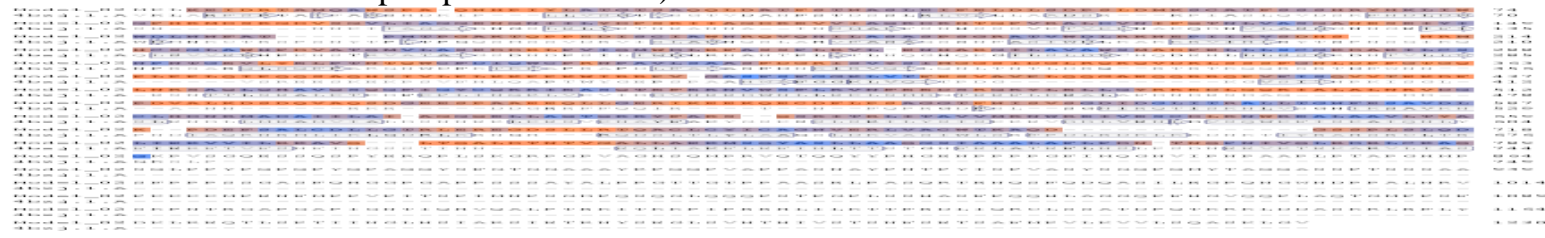

c) Atp5b protein [Musmusculus] target protein(2f43 selected as a reference structure for modeling of BH5 Atp5b protein [Musmusculus])

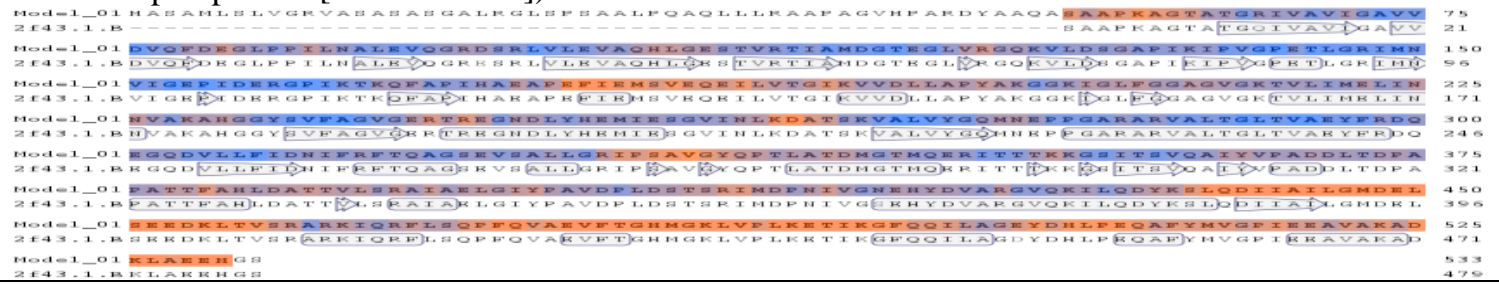

d) PREDICTED: polyadenylate-binding protein 4 isoform $\mathrm{X} 3$ target protein(4n0t selected as a reference structure for modeling of BPH3-PREDICTED: polyadenylate-binding protein 4 isoform X3).

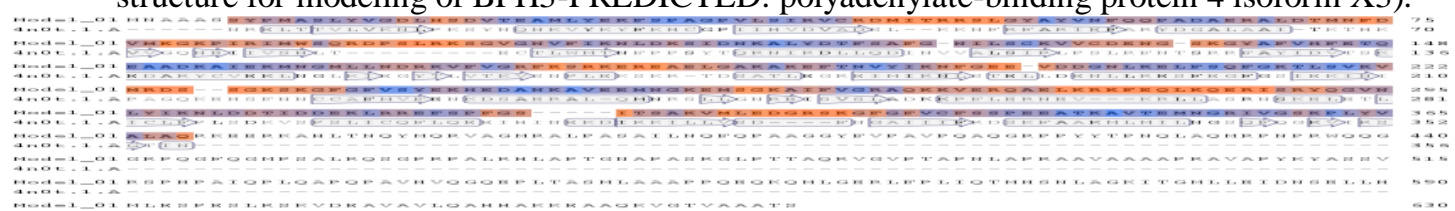

e) V-type proton ATPase catalytic subunit A target protein(3j9tselected as a reference structure for modeling of BPH4- V-type proton ATPase catalytic subunit A)

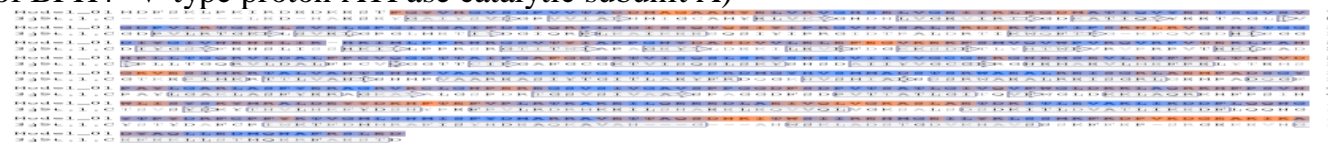

Fig 1:- Sequence alignment of differentially expressed proteins In hypothalamus induced by Bisphenol, Bisphenol and probiotic treated proteins. 
f) Mitochondrial ATP synthase, H+ transporting F1 complex beta subunit target protein(2f43 selected as a reference structure for modeling of BL 1500- Mitochondrial ATP synthase, H+ transporting F1 complex beta subunit).

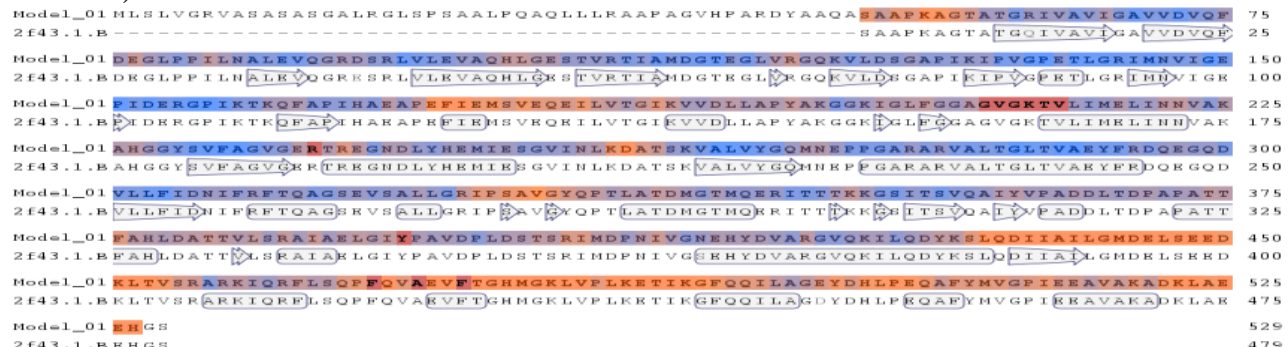

g) Laminin subunit alpha-5 precursor target protein(2y38selected as a reference structure for modeling of BL1549- Laminin subunit alpha-5 precursor).

SEqres APLAGGDGESLHPPYFHLAR GARITASATCGEBAPTRSVSRPTBDLYCKLVGGPVAGGDPAQTIQGQYCDICTAA 75

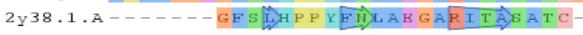

Seqres MSHKAHPVSHAIDGTBRWWQSPPLSRGLBYHBVHVTLDLGQVEHVAYVLIKFANSPRPDLWVLBRSTDEGHTYQP 150

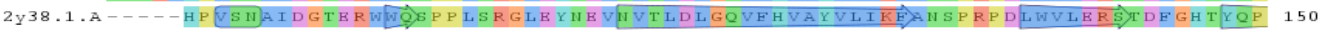

SEqres WQFFASSKRDCLBRFGPRTLBRITQDDDVICTTBYSRIVPLEHGBIVVSLVNGRPGALIFSYSPLLRDFTKATUI 225

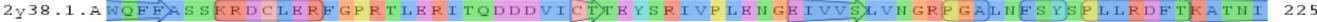

Seqres RLRELRTHTLLGHLMGKALRDPTVTRRYYYSIKDIS IGGRCVCHGHADVCDAKDPLDPERLOCACQHUTCGGSCD 300

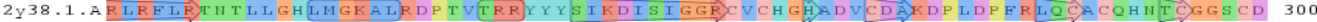

Seqres RCCPGEHQQPWKPATTDSAHECQSCHCHGHAYDCYYDPEVDRREASOHODHVYQGGGVCLDCOHHTTGIHCBRCL 375

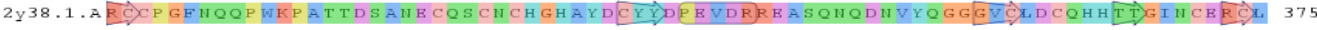

SEqres PGEFRAPDQPLDSPHVCRPAAAHHHHHH

2 Y38.1.APGEFBAPDQPLDSPHVCPEAAAH -

h) INSL3_MOUSE, Insulin-like 3 target protein(2kqp selected as a reference structure for modeling of BL1384-INSL3_MOUSE, Insulin-like 3).

Mode1_01 HRAPLLLMLLALGSALRSPQPPEARAKLCGHHLVRTLVRVCGGPR--WSPEATQPVETRDRELQWLEQRHLHA 73

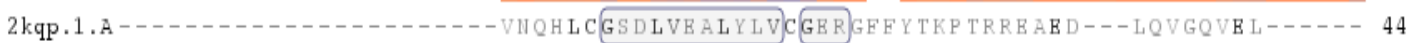

Mode1_01 LVADVDPALDPQLPRQASQRQRRSAATAVHRCCLTGCTQQDLLGLCPH

2kqp.1.A---GGGPGAGS-LQP LAL-BGSLQ-KRGIVBQCCT S I CS LYQLEITYCII - 86

i) Nucleolar protein 14 target protein(3zkv selected as a reference structure for modeling of BPL 119Nucleolar protein 14).

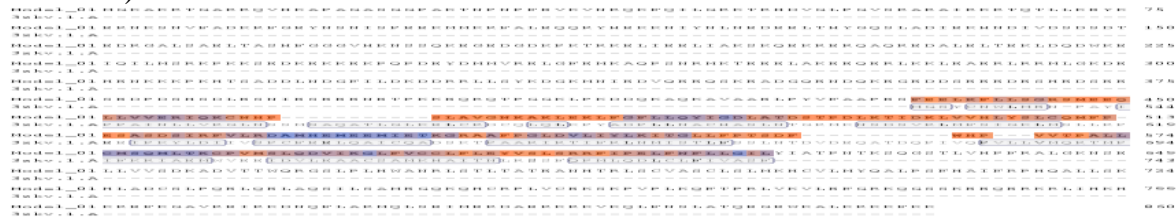

j) Nuclear protein MDM1 target protein (1wpbselected as a reference structure for modeling of BPL 128Nuclear protein MDM1).

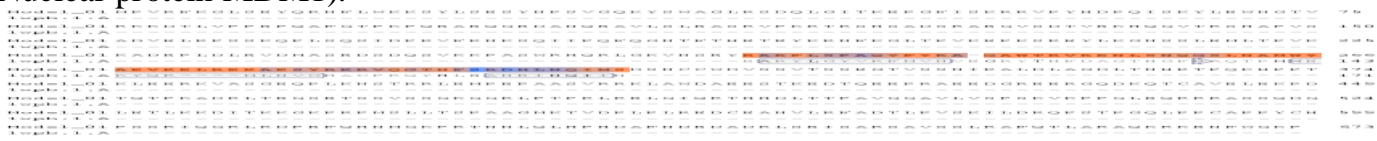

Fig 2:- Sequence alignment of differentially expressed proteins In liver induced by bisphenol, Bisphenol and probiotic treated proteins 


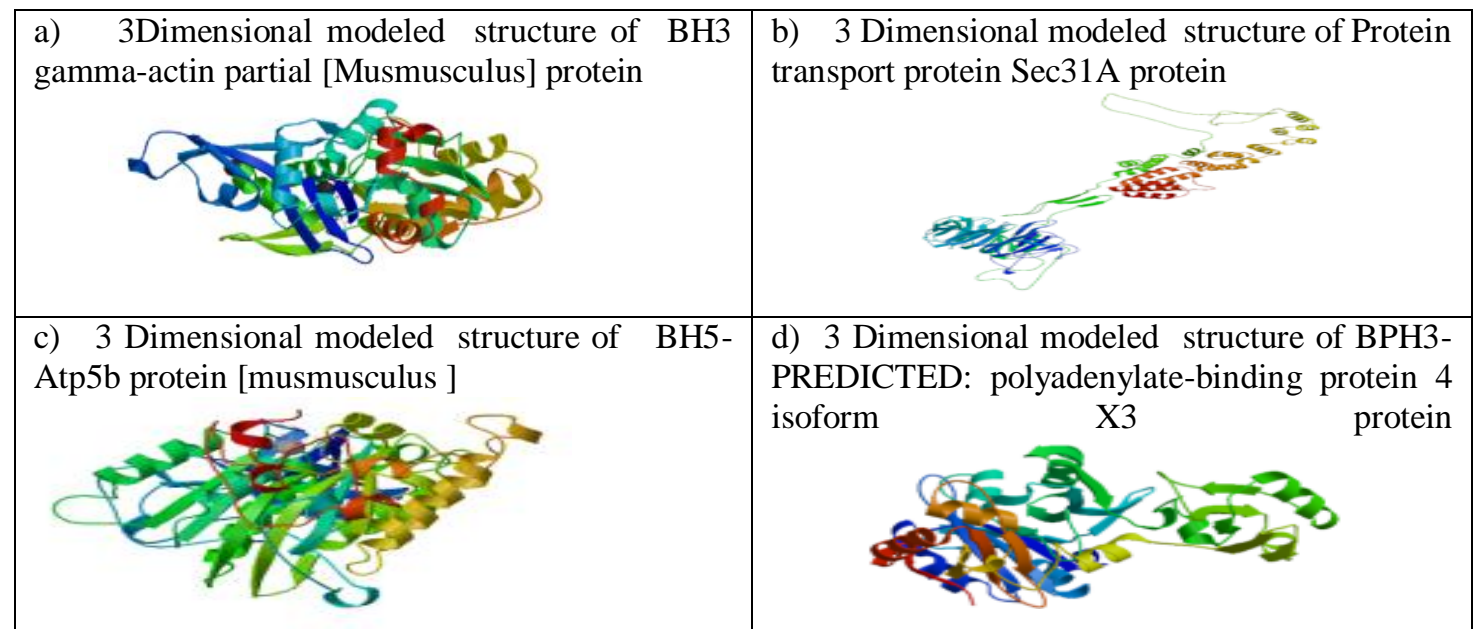

e) 3 Dimensional modeled structure of BPH4- V-type proton ATPase catalytic subunit A protein

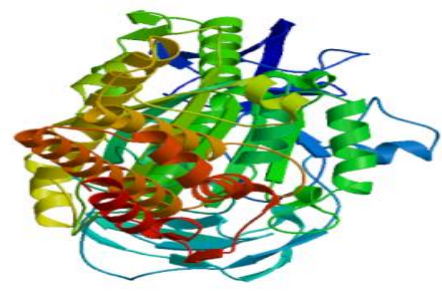

Fig 3:- Homology modeling of differentially expressed proteins of Hypothalamus induced by Bisphenol A and treatement with BPA+probiotic bacteria

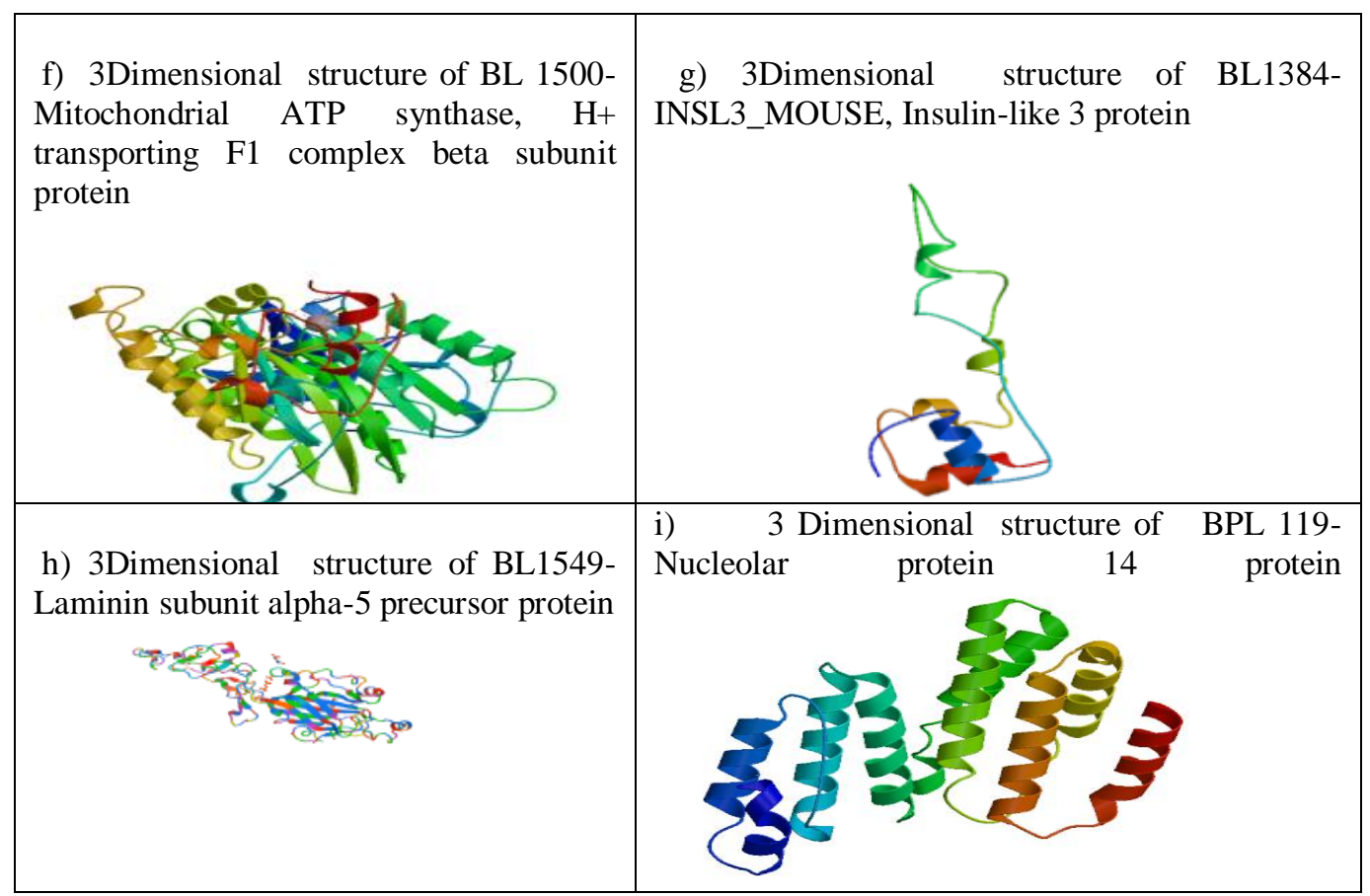


j) 3Dimensional structure of BPL 128-Nuclear protein MDM1 protein

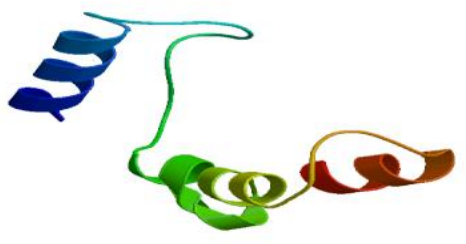

Fig 4:- Homology modeling of differentially expressed proteins of Liver induced by BPA and treatemnt with BPA + probiotc bacteria

Table 3:- Validation of Hypothalamus tissue protein sample by Ramachandran's plot analysis

\begin{tabular}{|l|l|l|l|l|}
\hline S.No & No. of residues in most favoured regions & $\begin{array}{l}\text { No.of residues } \\
\text { in additional } \\
\text { allowed regions }\end{array}$ & $\begin{array}{l}\text { No.of residues in } \\
\text { disallowed regions }\end{array}$ & $\begin{array}{l}\text { No.of glycine and } \\
\text { proline residues }\end{array}$ \\
\hline $\mathbf{1 .}$ & gamma-actin,partial [Musmusculus] & $277(87.7 \%)$ & $38(12.0 \%)$ & $28(\mathrm{Gly}), 19(\mathrm{pro})$ \\
\hline $\mathbf{2 .}$ & Protein transport protein Sec31A & $455(74.5 \%)$ & $127(20.8 \%)$ & $41(\mathrm{Gly}), 29(\mathrm{pro})$ \\
\hline $\mathbf{3 .}$ & Atp5b protein [Musmusculus] & $363(91.9 \%)$ & $30(7.6 \%)$ & $45(\mathrm{Gly}), 24(\mathrm{pro})$ \\
\hline $\mathbf{4 .}$ & $\begin{array}{l}\text { PREDICTED: polyadenylate-binding } \\
\text { protein 4 isoform X3 }\end{array}$ & $284(87.1 \%)$ & $31(9.6 \%)$ & $28(\mathrm{Gly}), 9(\mathrm{pro})$ \\
\hline $\mathbf{5 .}$ & V-type proton ATPase catalytic subunit A & $458(83.4 \%)$ & $50(9.7 \%)$ & $50(\mathrm{Gly}), 30(\mathrm{pro})$ \\
\hline
\end{tabular}

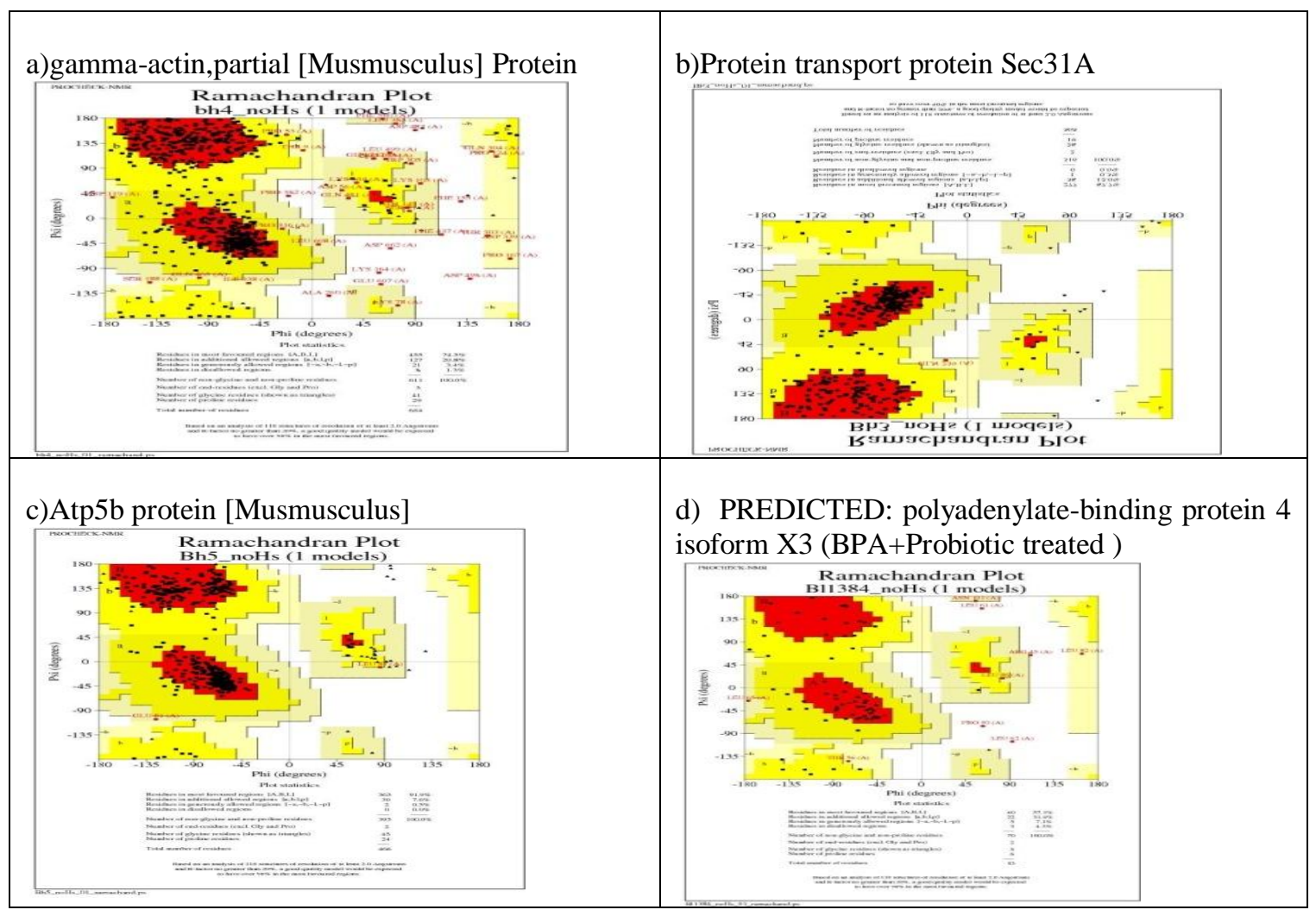


e) V-type proton ATPase catalytic subunit A(BPA+Probiotic treated).

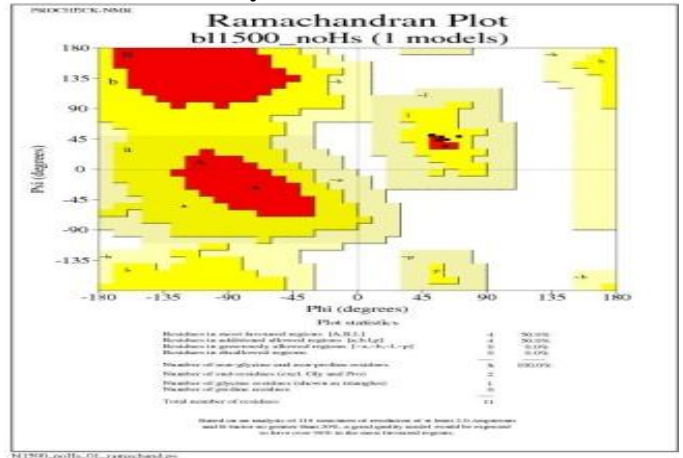

Fig 5:- Illustration of Ramachandran's plot analysis of proteins expressed in Hypothalamus response to BPA stress and BPA+Probiotic treatement

Table 4: Validation of Liver tissue proteins by Ramachandran's plot analysis

\begin{tabular}{|l|l|l|l|l|}
\hline S.No & No. of residues in most favoured regions & $\begin{array}{l}\text { No.of residues in } \\
\text { additional allowed } \\
\text { regions }\end{array}$ & $\begin{array}{l}\text { No.of residues in } \\
\text { disallowed regions }\end{array}$ & $\begin{array}{l}\text { No.of glycine and } \\
\text { proline residues }\end{array}$ \\
\hline 6. & INSL3_MOUSE, Insulin-like 3 & $40(57.1 \%)$ & $22(31.4 \%)$ & $5(\mathrm{Gly}), 6(\mathrm{pro})$ \\
\hline $\mathbf{7 .}$ & $\begin{array}{l}\text { Mitochondrial ATP synthase, H+ } \\
\text { transporting F1 complex beta subunit }\end{array}$ & $4(50.0 \%)$ & $4(50.0 \%)$ & $1(\mathrm{Gly}), 0(\mathrm{pro})$ \\
\hline $\mathbf{8 .}$ & Laminin subunit alpha-5 precursor & $44(50.0 \%)$ & $4(50.0 \%)$ & $1(\mathrm{Gly}), 0$ (pro) \\
\hline $\mathbf{9 .}$ & Nucleolar protein 14 & $103(89.6 \%)$ & $11(9.6 \%)$ & $5(\mathrm{Gly}), 7(\mathrm{pro})$ \\
\hline $\mathbf{1 0 .}$ & Nuclear protein MDM1 & $4(50.0 \%)$ & $4(50.0 \%)$ & $1(\mathrm{Gly}), 0(\mathrm{pro})$ \\
\hline
\end{tabular}

f) INSL3_MOUSE, Insulin-like 3

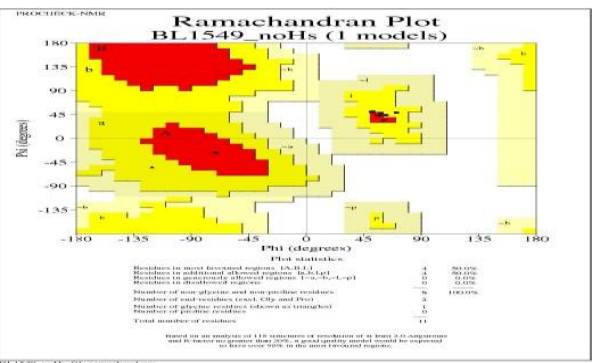

h) Laminin subunit alpha-5 precursor

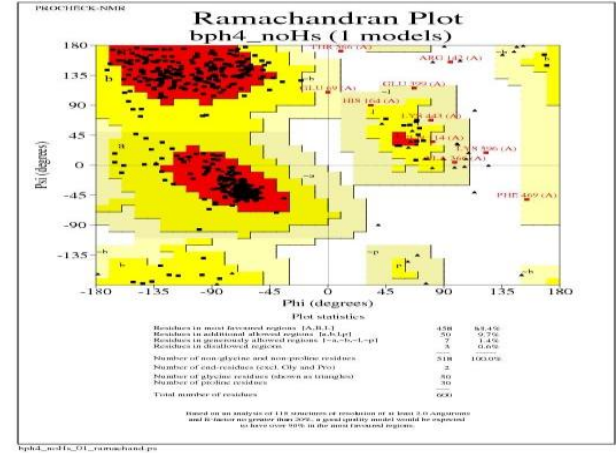

g) Mitochondrial ATP synthase, $\mathrm{H}+$ transporting F1 complex beta subunit

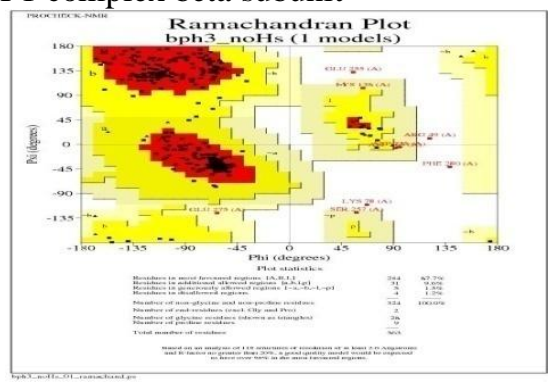

i) Nucleolar protein 14

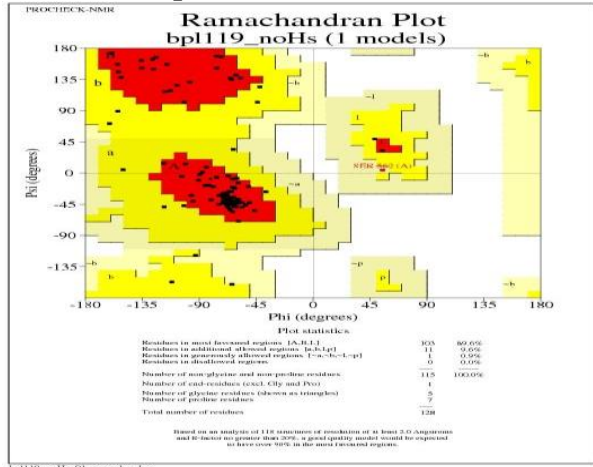




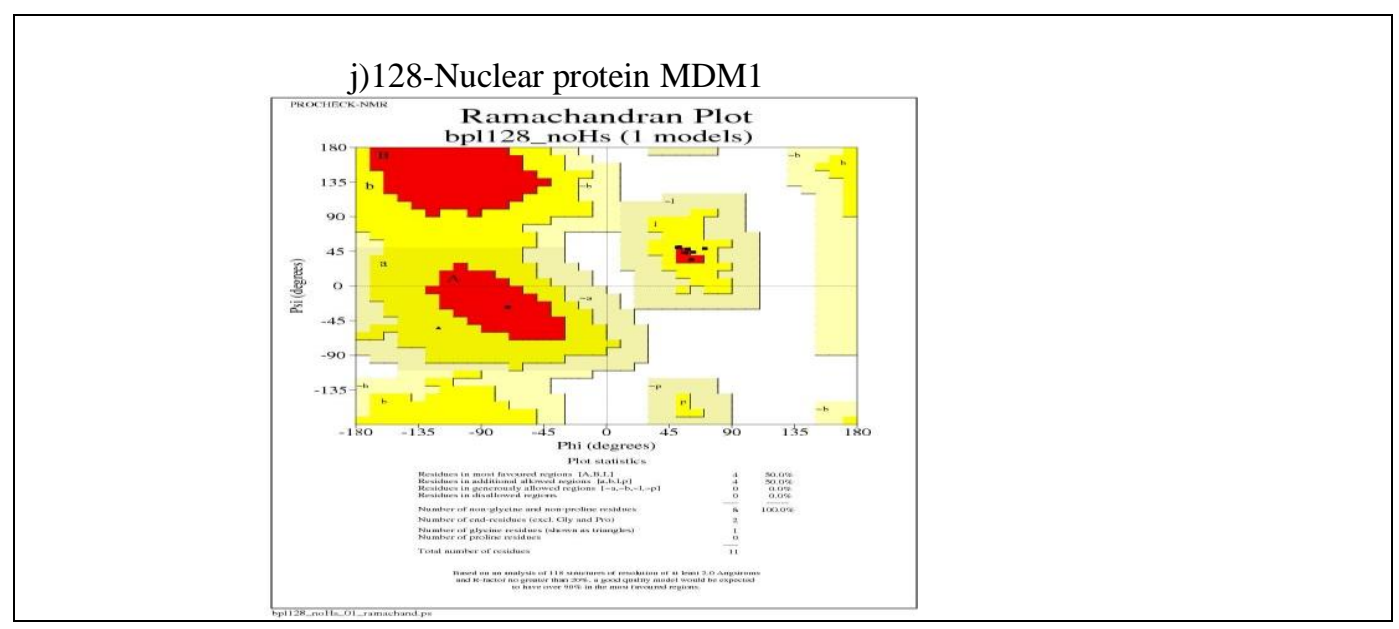

Fig 6:- Ramachandran's plot analysis of proteins expressed in Liver response to BPA stress and BPA+Probiotic treatement.

\begin{tabular}{|c|c|c|}
\hline a)Quality of resolution structure of -gamma-actin, & QMEAN scoring function o & f gamma-actin, partia[Mu \\
\hline partial [Musmusculus] protein & Protein model name & $\mathrm{BH} 3$ \\
\hline 1 & Zscore_QMEAN & 0.202664453420632 \\
\hline $\begin{array}{lll}C B \text { interaction } & \mathbf{1}, \begin{array}{l}-1.04 \\
-0.16\end{array} \\
\text { all-atom interaction } & \mathbf{1}\end{array}$ & Zscore_Cbeta & 1.03958792614991 \\
\hline $\begin{array}{l}\text { solvation } \\
\text { torsion }\end{array}$ & Zscore_all_atom & 0.161708866011722 \\
\hline SSE agreement 1 & Zscore_solvation & 0.622112948131572 \\
\hline 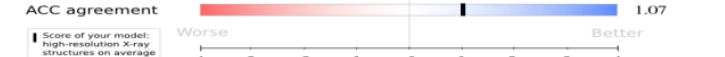 & Zscore_torsion & 1.76687838179354 \\
\hline $\begin{array}{llllll}-3 & -1 & 0 \\
\text { z-score } & 1 & 2\end{array}$ & Zscore_SSE_agree & 0.721091515598544 \\
\hline & Zscore_ACC_agree & 1.06896443585087 \\
\hline b) Quality of resolution structure of Protein & QMEAN scoring function o & f Protein transport protein \\
\hline amean & Protein model name & $\mathrm{BH} 4$ \\
\hline $\begin{array}{l}\mathrm{C}_{\mathrm{C} \text { interaction }} \\
\text { all-atom interaction }\end{array}$ & Zscore_QMEAN & 2.19243199536967 \\
\hline $\begin{array}{l}\text { all-atom interaction } \\
\text { solvation }\end{array}$ & Zscore_Cbeta & 0.109382670524617 \\
\hline 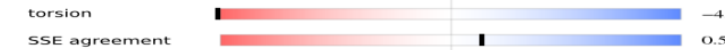 & Zscore_all_atom & 0.0201402306006502 \\
\hline Acc agreement 1 & Zscore_solvation & 1.34093329731162 \\
\hline 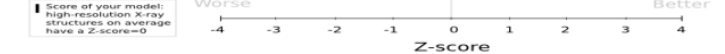 & Zscore_torsion & 4.25948482492861 \\
\hline & Zscore_SSE_agree & 0.560296498026475 \\
\hline & Zscore_ACC_agree & 1.14302010241546 \\
\hline & QMEAN scoring function of & If Atp5b protein [Musmusc \\
\hline c) Quality of resolution structure of Atp5b protein & Protein model name & BH5 \\
\hline [Musmusculus] protein & Zscore_QMEAN & 0.508027357752407 \\
\hline $1=0$ & Zscore_Cbeta & 0.469305344908218 \\
\hline 1 & Zscore_all_atom & 0.439180122160005 \\
\hline 1 & Zscore_solvation & 1.59520535256758 \\
\hline SSE agreement & Zscore_torsion & 0.592791846376968 \\
\hline 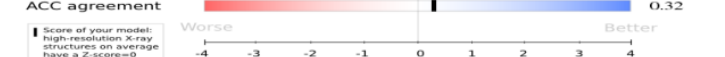 & Zscore_SSE_agree & 0.180361826190693 \\
\hline 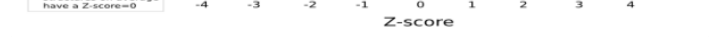 & Zscore_ACC_agree & 0.323508715703452 \\
\hline
\end{tabular}




\begin{tabular}{|c|c|c|}
\hline \multirow{3}{*}{$\begin{array}{l}\text { d) Quality of resolution structure of } \\
\text { PREDICTED: polyadenylate-binding protein } 4 \\
\text { isoform X3 protein }\end{array}$} & \multicolumn{2}{|c|}{ QMEAN scoring function of -PREDICTED: polyadenylate-binding } \\
\hline & Protein model name & BPH3 \\
\hline & Zscore_QMEAN & 2.64365830791129 \\
\hline \multirow{4}{*}{ 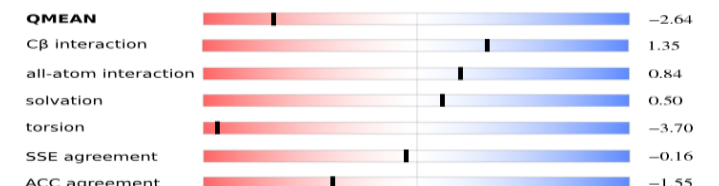 } & Zscore_Cbeta & 1.35236987594616 \\
\hline & Zscore_all_atom & 0.841938004887182 \\
\hline & Zscore_solvation & 0.500248807406608 \\
\hline & Zscore_torsion & 3.70379067315507 \\
\hline \multirow{3}{*}{ 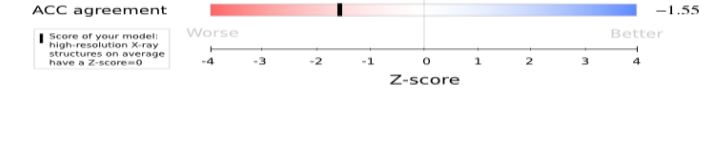 } & Zscore_SSE_agree & 0.161966738028873 \\
\hline & Zscore_ACC_agree & 1.54929393635679 \\
\hline & \multicolumn{2}{|l|}{ protein 4 isoform $\mathrm{X} 3$} \\
\hline \multirow{3}{*}{$\begin{array}{l}\text { e)Quality of resolution structure of V-type proton } \\
\text { ATPase catalytic subunit A protein }\end{array}$} & \multicolumn{2}{|c|}{ QMEAN scoring function of V-type proton ATPase catalytic } \\
\hline & Protein model name & BPH4 \\
\hline & Zscore_QMEAN & 1.18765547487996 \\
\hline \multirow{2}{*}{ 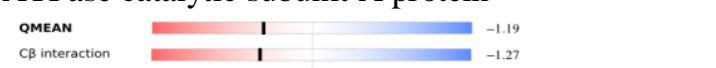 } & Zscore_Cbeta & 1.26927752065401 \\
\hline & Zscore_all_atom & 1.39075172759304 \\
\hline $\begin{array}{lll}\text { all-atom interaction } & \mathbf{I} & -1.39 \\
\text { solvation } & \mathbf{I} & -0.96\end{array}$ & Zscore_solvation & 0.963680705267424 \\
\hline \multirow{2}{*}{ 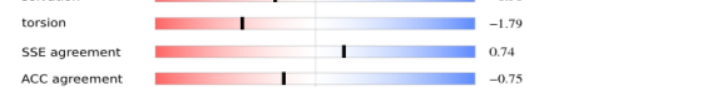 } & Zscore_torsion & 1.79409653465914 \\
\hline & Zscore_SSE_agree & 0.744410029116678 \\
\hline Accogrement & Zscore_ACC_agree & 0.752399634822914 \\
\hline 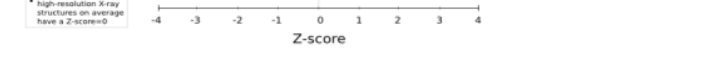 & \multicolumn{2}{|l|}{ subunit A } \\
\hline
\end{tabular}

Fig 7:- QMEAN analysis for the quality resolution structure of Hypothalamus proteins induced with BPA and BPA+Probiotic treatement.

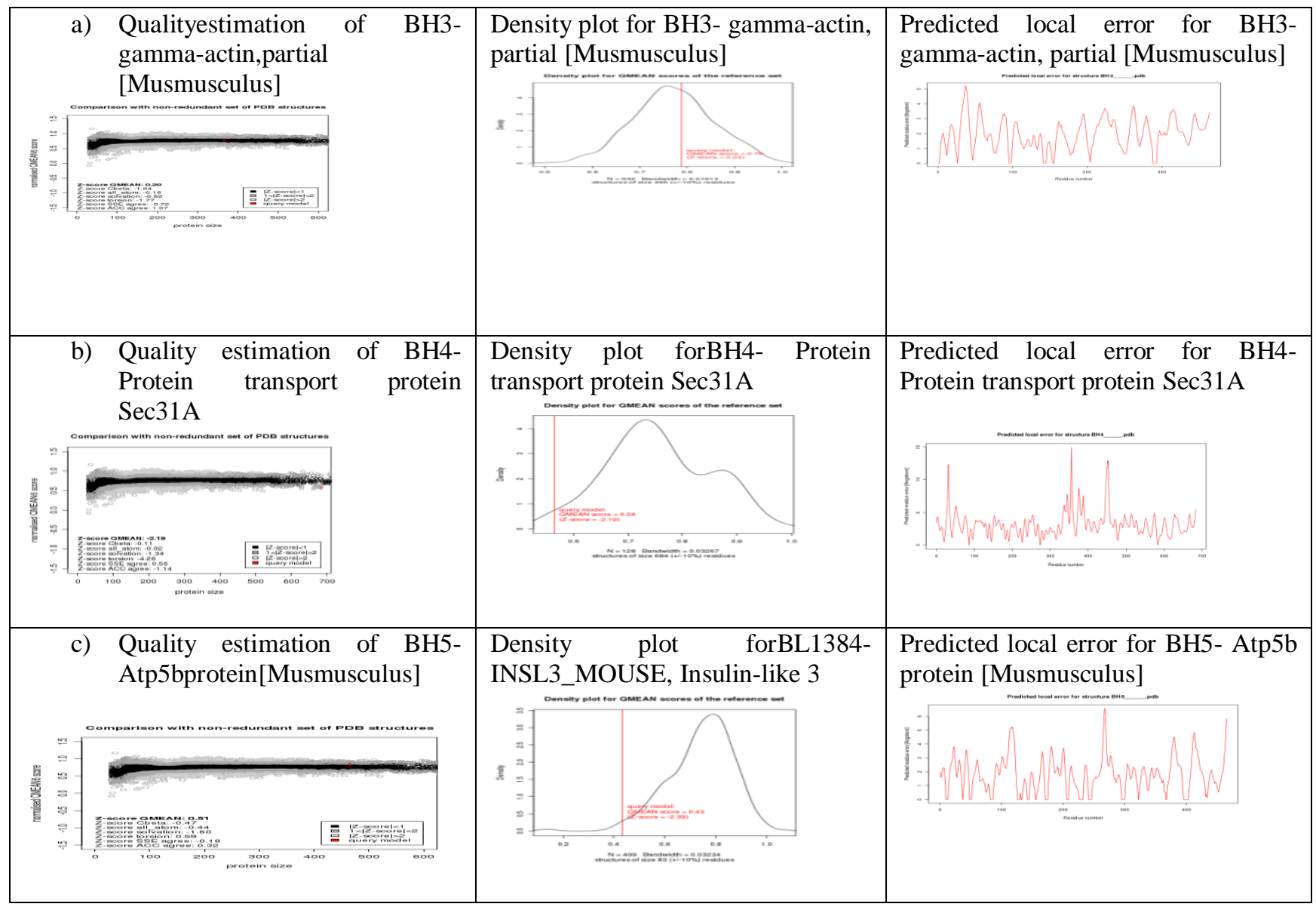




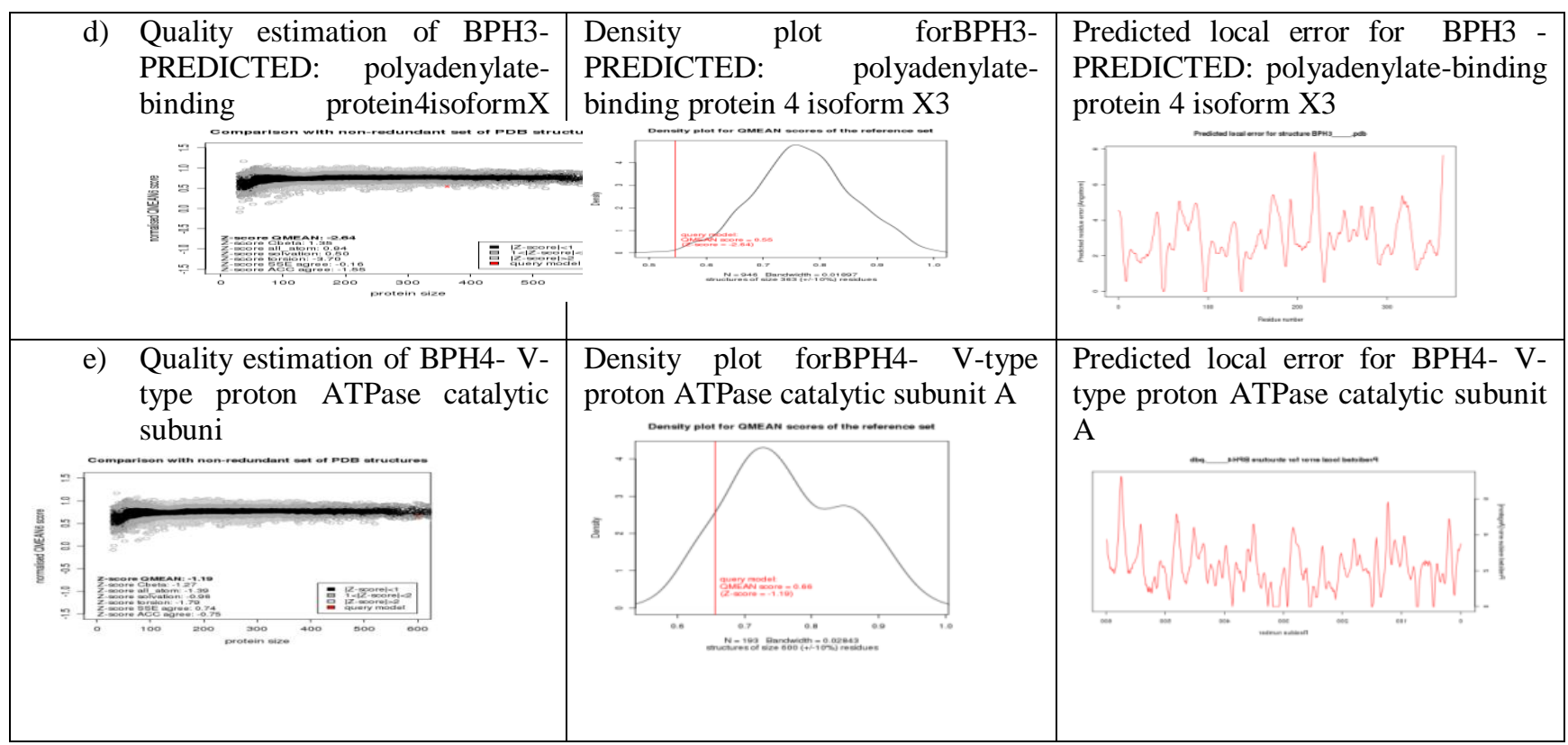

Fig 8:- Qmean Analysis,Density Plot Analysis ,Predicted Local Error for estimating the quality of differentially expressed proteins structure of Hypothalamus tissue induced with BPA and BPA+Probiotic treatement

\begin{tabular}{|c|c|c|}
\hline $\begin{array}{l}\text { f)Quality of resolution structure of } 1384- \\
\text { INSL3_MOUSE, Insulin-like } 3 \text { protein }\end{array}$ & Protein model name & BL1384 \\
\hline \multirow{2}{*}{$\begin{array}{l}\text { OMEAN } \\
\text { CB interaction } \\
\text { all-atom interaction }\end{array}$} & Zscore_QMEAN & 2.38964453671237 \\
\hline & Zscore_Cbeta & 0.127878246354725 \\
\hline solvation $\quad$ I -0.40 & Zscore_all_atom & 0.597864567752103 \\
\hline $\begin{array}{l}\text { torsion } \\
\text { SSE agreement }\end{array}$ & Zscore_solvation & 0.4017765313089 \\
\hline 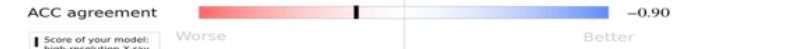 & Zscore_torsion & 3.97626544639136 \\
\hline 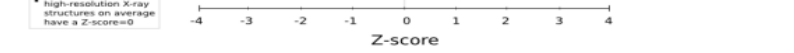 & Zscore_SSE_agree & 0.436430019683796 \\
\hline & Zscore_ACC_agree & 0.895632370321055 \\
\hline \multirow{3}{*}{$\begin{array}{l}\text { g)Quality of resolution structure of 1500- } \\
\text { Mitochondrial ATP synthase, H+ transporting F1 } \\
\text { complex beta subunit protein }\end{array}$} & \multirow[b]{2}{*}{ Protein model name } & \\
\hline & & BL1500 \\
\hline & Zscore_QMEAN & 0.508027357752407 \\
\hline \multirow{5}{*}{ 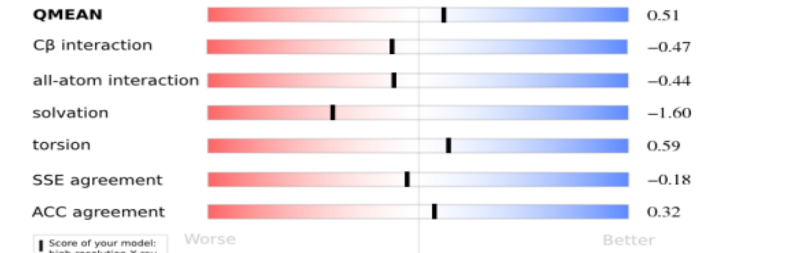 } & Zscore_Cbeta & 0.469305344908218 \\
\hline & Zscore_all_atom & 0.439180122160005 \\
\hline & Zscore_solvation & 1.59520535256758 \\
\hline & Zscore_torsion & 0.592791846376968 \\
\hline & ZscoreSSEagree & 0.180361826190693 \\
\hline 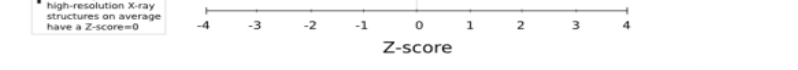 & ZscoreACCagree & 0.323508715703452 \\
\hline \multirow{5}{*}{$\begin{array}{l}\text { h)Quality of resolution structure of } 1549 \text { - Laminin } \\
\text { subunit alpha-5 precursor protein }\end{array}$} & \multicolumn{2}{|c|}{$\begin{array}{l}\text { QMEAN scoring function of BL1549- Laminin subunit } \\
\text { alpha-5 precursor }\end{array}$} \\
\hline & Protein model name & BL1549 \\
\hline & Zscore_QMEAN & 1.66677810992402 \\
\hline & Zscore_Cbeta & 0.895601151162753 \\
\hline & Zscore_all_atom & 0.567516734841358 \\
\hline
\end{tabular}




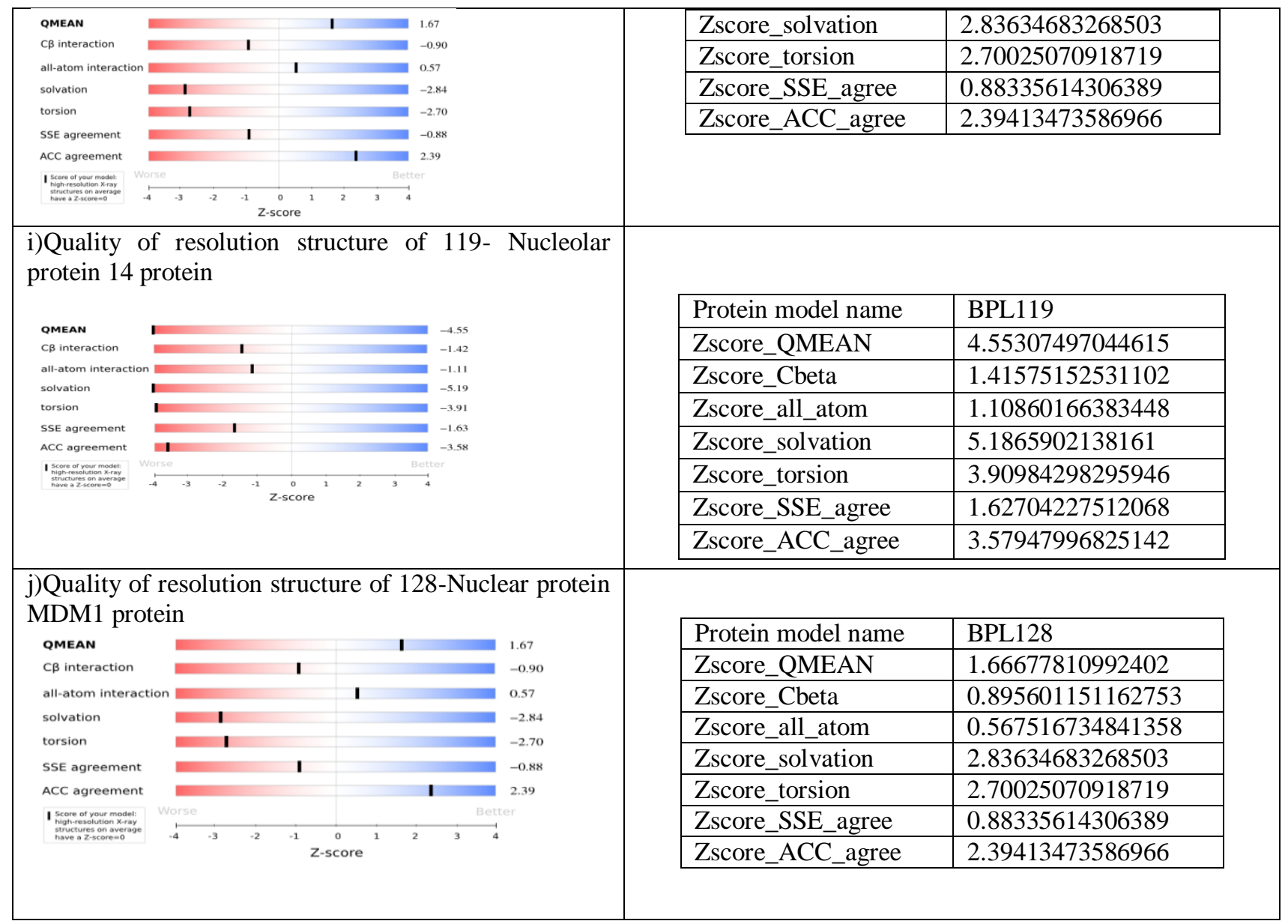

Fig 9:- QMEAN analysis for the quality resolution structure of Liver proteins induced with BPA and BPA+Probiotic treatement.

\begin{tabular}{|c|c|c|}
\hline 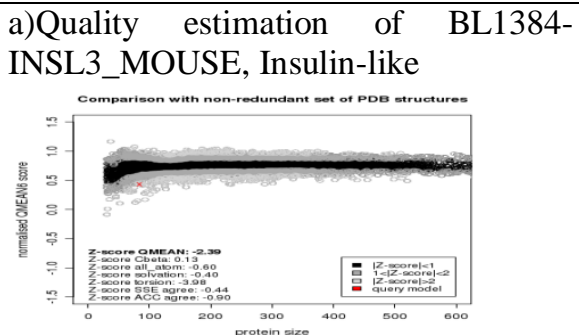 & $\begin{array}{l}\text { Density plot forBL1384- } \\
\text { INSL3_MOUSE, Insulin-like 3 }\end{array}$ & $\begin{array}{l}\text { Predicted local error for BL1384- } \\
\text { INSL3_MOUSE, Insulin-like } 3\end{array}$ \\
\hline 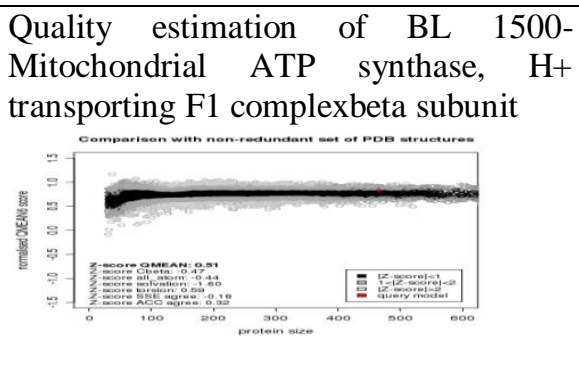 & $\begin{array}{l}\text { Density plot forBL 1500- } \\
\text { Mitochondrial ATP synthase, H+ } \\
\text { transporting F1 complex beta } \\
\text { subuniT }\end{array}$ & $\begin{array}{l}\text { Predicted local error for BL 1500- } \\
\text { Mitochondrial ATP synthase, H+ } \\
\text { transporting F1 complex beta subunit }\end{array}$ \\
\hline
\end{tabular}




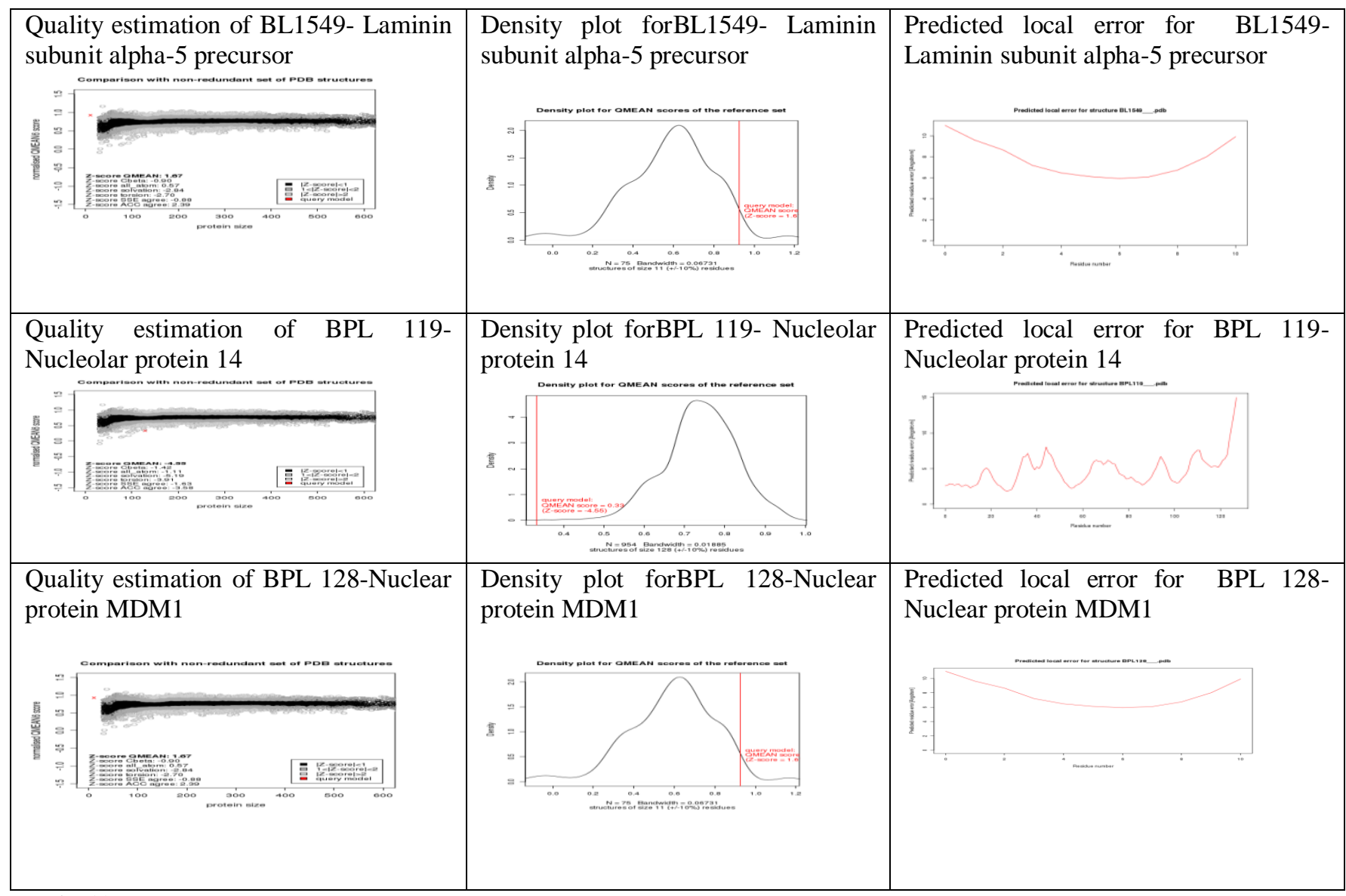

Fig 10:- Qmean Analysis,Density Plot Analysis ,Predicted Local Error for estimating the quality of differentially expressed proteins structure of Liver tissue induced with BPA and BPA+Probiotic treatement

\begin{tabular}{|c|c|c|}
\hline \multicolumn{2}{|c|}{ Prot para analysis of gamma-actin, partial [Musmusculus] protein } & \multirow{9}{*}{$\begin{array}{l}\text { String structure of gamma-actin, partial } \\
\text { [Musmusculus }\end{array}$} \\
\hline Formula of the protein & $\mathrm{C} 1822 \mathrm{H} 2860 \mathrm{~N} 484 \mathrm{O} 548 \mathrm{~S} 22$ & \\
\hline Total No.of atoms & 5736 & \\
\hline Extinction coefficient & 44725 & \\
\hline Molecular weight & 41018.9 Daltons & \\
\hline Estimated half-life & 5.5 & \\
\hline Instability index & 36.18 ( Stable Protein) & \\
\hline Aliphatic index & 82.17 & \\
\hline $\begin{array}{|lr|}\text { GRAVY } & \text { (Grand } \\
\text { average } & \text { of } \\
\text { hydropathicity) } & \\
\end{array}$ & -0.201 & \\
\hline \multicolumn{2}{|c|}{ Prot param analysis of Protein transport protein Sec31A } & \multirow{9}{*}{$\begin{array}{l}\text { String structure of Protein transport } \\
\text { protein } \operatorname{Sec} 31 \mathrm{~A}\end{array}$} \\
\hline Formula of the protein & $\begin{array}{l}\text { C5910H9310N1638O1811S4 } \\
0\end{array}$ & \\
\hline Total No.of atoms & 18709 & \\
\hline Extinction coefficient & 129355 & \\
\hline Molecular weight & 133569.2 Daltons & \\
\hline Estimated half-life & 30 hours & \\
\hline Instability index & 54.48 ( Unstable Protein) & \\
\hline Aliphatic index & 79.21 & \\
\hline GRAVY(Grand average & -0.376 & \\
\hline
\end{tabular}




\begin{tabular}{|c|c|c|c|}
\hline \multicolumn{2}{|l|}{ Total No.of atoms } & 8000 & \\
\hline \multicolumn{2}{|l|}{ Extinction coefficient } & 19370 & \\
\hline \multicolumn{2}{|l|}{ Molecular weight } & 56300.4 Daltons & \\
\hline \multicolumn{2}{|l|}{ Estimated half-life } & 30 hours & \\
\hline \multicolumn{2}{|l|}{ Instability index } & 35.18 ( stable protein) & \\
\hline \multicolumn{2}{|l|}{ Aliphatic index } & 100.34 & \\
\hline \multicolumn{3}{|c|}{\begin{tabular}{|l}
$\begin{array}{l}\text { GRAVY(Grand average of } \\
\text { hydropathicity) }\end{array}$ \\
\end{tabular}} & \\
\hline \multicolumn{3}{|c|}{ Protparam analysis of Laminin subunit alpha-5 precursor } & \multirow{9}{*}{$\begin{array}{l}\text { String structure of Laminin subunit alpha- } 5 \\
\text { precursor }\end{array}$} \\
\hline Formula of the protein & \multicolumn{2}{|c|}{ C17541H27400N5124O5339S267 } & \\
\hline Total No.of atoms & \multicolumn{2}{|c|}{55671} & \\
\hline Extinction coefficient & \multicolumn{2}{|c|}{345030} & \\
\hline \begin{tabular}{|l|} 
Molecular weight \\
\end{tabular} & \multicolumn{2}{|c|}{ 404053.6 Daltons } & \\
\hline Estimated half-life & \multicolumn{2}{|c|}{30 hours } & \\
\hline Instability index & \multicolumn{2}{|c|}{47.78 ( Unstable Protein) } & \\
\hline Aliphatic index & \multicolumn{2}{|c|}{72.87} & \\
\hline \begin{tabular}{|l|}
$\begin{array}{l}\text { GRAVY(Grand average of } \\
\text { hydropathicity) }\end{array}$ \\
\end{tabular} & \multicolumn{2}{|c|}{-0.289} & \\
\hline \multicolumn{3}{|c|}{ Prot param analysis of Nucleolar protein 14} & \multirow{9}{*}{ String structure of Nucleolar protein 14} \\
\hline Formula of the protein & \multicolumn{2}{|c|}{ C4319H6963N1243O1334S35 } & \\
\hline \begin{tabular}{|l|} 
Total No.of atoms \\
\end{tabular} & \multicolumn{2}{|c|}{13894} & \\
\hline Extinction coefficient & \multicolumn{2}{|c|}{49110} & \\
\hline Molecular weight & \multicolumn{2}{|c|}{ 98769.4 Daltons } & \\
\hline Estimated half-life & \multicolumn{2}{|c|}{30 hours } & \\
\hline Instability index & \multicolumn{2}{|c|}{54.74 ( Unstable Protein) } & \\
\hline Aliphatic index & \multicolumn{2}{|c|}{73.63} & \\
\hline $\begin{array}{l}\text { GRAVY(Grand average of } \\
\text { hydropathicity) }\end{array}$ & \multicolumn{2}{|c|}{-0.843} & \\
\hline \multicolumn{3}{|c|}{ Protparam analysis of Nuclear protein MDM1 } & \multirow{9}{*}{ String structure of Nuclear protein MDM1 } \\
\hline Formula of the protein & \multicolumn{2}{|c|}{ C3285H5255N991O1035S15 } & \\
\hline Total No.of atoms & 105 & & \\
\hline Extinction coefficient & 707 & & \\
\hline Molecular weight & 756 & 73.4 Daltons & \\
\hline \begin{tabular}{|l|} 
Estimated half-life \\
\end{tabular} & 301 & ours & \\
\hline \begin{tabular}{|l} 
Instability index \\
\end{tabular} & 50. & 66 (Unstable Protein) & \\
\hline Aliphatic index & 61. & & \\
\hline $\begin{array}{l}\text { GRAVY(Grand average of } \\
\text { hydropathicity) }\end{array}$ & \begin{tabular}{l|l}
$f$ \\
$f$
\end{tabular} & & \\
\hline
\end{tabular}

Fig 12:- Prot param and string analysis of expressed proteins in Liver tissue response to BPA and BPA+probiotic treatement

\section{Discussion:-}

In the present study, we have identified the structures and complete protein information regarding 3D structures, atomic configurations, no.of amino acid residues in ramachandrans plot analysis of BPA stressed liver proteins and BPA and probiotic treated Hypothalamus tissue proteins. We were interested in BPA induced proteins in liver as they were over expressed and this over expression in normal cellular metabolism may lead to the diseases.

INSL3_MOUSE,insulin-like3 protein:-

This protein is a member of the insulin like hormone or protein super family and was first recognized by cloning projects using testicular tissue, hence its original name of Leydig insulin-like peptide [12,13 ] and also expressed in 
ovarian theca and luteal cells in females. Although recognized for some time, its function was unknown until 1999 when two groups investigating mice mutants for INSL3 found bilateral cryptorchidism and developmental abnormalities of the gubernaculums [14,15] in males. It is the Newest hormone or protein demonstrated to be involved in abnormalities like:

Testicular descent or cryptorchidism and Gubernacular swelling:-

INSL3/Leydig insulin-like peptide acts as a ligand and activates the LGR8 receptor (G-protein coupled receptor) present on testes cells, important in testis descent. This LGR8 receptor activation leads to Signalling process and INSL3 peptide continous signalling or mutation leads to a condition called cryptorchidism in which testicle that doesn't move into its proper position in the bag of skin hanging below the penis (scrotum). In humans, circulating INSL3 increases through puberty, to reach a maximum in early adulthood, and subsequently appears to decline to significantly lower plasma levels in aging men [16, 17]. Recently, it has been suggested [18] that androgens and phthalates at high concentration may modulate Insl3 gene expression in cultured Leydig cells. Caudal enlargement of the gubernaculum during relative transabdominal movement of the testis is known as the "gubernacular swelling reaction" or "gubernacular outgrowth" and is caused by cell division and an increase in glycosaminoglycans and hyaluronic acid (19). The hydrophilic nature of hyaluronic acid makes the end of the gubernaculum bulky and gelatinous. In females over expression of INSL3 induces ovary descent.

\section{Mitochondrial ATP synthase, H+ transporting F1 complex beta subunit protein:-}

Mitochondrial ATP5B expression in the liver has been shown to be controlled at the post-transcriptional level (and controlling process was found to be induced by miR-127-5p) .MiR-127-5p 3'UTR of $\beta$-F1-ATPase which shows much expression in fetal liver targets mRNA ( $\beta$-mRNA) and miR-127-5p inhibits $\beta$-F1-ATPase mRNA translation in humans [20]. MiR-127-5p has an important role in regulating the activity of mitochondrial bioenergetics in oncogenesis[21]. ATP5B was found to be up regulated in breast cancer in tissues in a significant manner. Control of translational efficiency of beta-F1- ATPase mRNA depends on the regulation of a protein that binds the 3' untranslated region of the m RNA. miR-127-5p inhibits $\beta$-F1-ATPase mRNA translation in humans.

\section{Counter effect on ATP synthase:-}

The agonist of ATP synthase MAb3D5AB1 recognises catalytic $\beta$-subunit of ATP synthase and inhibits the activity of F1domain. Mab3d5ab1 shows angiostatin-like properties and can be useful in the chemotheraaphy... This protein can even play an important role as a target protein in the treatment of cancers. Using ATP synthase inhibitor aurovertin B, in breast cancer cells MCF-7, the effect of ATP5B protein in tumor progression was found to be reduced. [22].

\section{Laminin subunit alpha-5 precursor protein:-}

This protein contains five, $\underline{\mathrm{N} \text {-terminus, }}$, extracellular immunoglobulin domains, a single transmembrane domain, and a short, $\mathrm{C}$-terminal cytoplasmic tail and may play a role in epithelial cell cancer and in vaso-occlusion of red blood cells in sickle cell disease. More recent data indicate a direct participation of the vascular endothelium, of multiple and complex cellular interactions, and of a global inflammation-mediated cell activation, in the initiation and propagation of the vaso-occlusive process with two consecutive steps. The first step involves adhesion of the stress reticulocytes[23] and activated polymorphonuclear neutrophils8, (iii) signalling pathways in the red blood ( the signalling pathways in the red blood cell, makes the cell susceptible to be modulated by stress, hypoxia, and by the inflammatory response and to influence the activation status of adhesion receptors and of ion transporters implicated in SS-RBC dehydration and finally of a syndrome of complex endothelial dysfunction involving abnormalities of the metabolism of nitric oxide (NO) )was brought into light to the endothelium of post-capillary veinules, slowing down the blood flow and thereby inducing and propagating sickling of mature SS-RBCs that are maintained for a longer time in a hypoxic environment and activates polymorphonuclear neutrophils second step involves the entrapment of irreversible sickle cells and to the complete occlusion of the micro-vessels[24-31]

\section{Conclusion:-}

In our study, we concluded that BPA stressed proteins in liver tissue are involved in certain metabolic disorders like cryptorchidism, Gubernacular swelling, oncogenesis, epithelial cell cancers and Vaso-occlusive process where BPA and probiotic treatement in liver shown production of Nuclear protein MDM1 protein which is a microtubulebinding protein that negatively regulates centriole duplication which binds and stabilizes microtubules in controlling cell duplication process in testis. This negative regulation seems to be to control the cryptochidism caused by over expressed proteins by BPA in liver. 


\section{Conflict Of Interest:-}

We declare that we have no conflict of interest.

\section{Acknowledgement:-}

The authors are thankful to UGC, New Delhi for providing financial assistance ( UGC-MRP).

\section{References:-}

1. Kush,A. and Raghava, GPS.(2008):AC2DGel: Analysis and Comparison of 2D Gels. J Proteomics Bioinform,1: 043-046.

2. Zhang,Z.H., Hongzhan,H., Amrita,C., Mira,J., Anatoly,D.(2008):Integrated Bioinformatics for RadiationInduced Pathway Analysis from Proteomics anMicroarray Data. J Proteomics Bioinform, 1:047-060.

3. Teeguarden,J.G., Waechter,JMJr., Clewell,H.J., Covington,T.R., Barton,H.A.(2005): Evaluation of oral and intravenous route pharmacokinetics, plasma binding protein, and uterine tissue dose metrics of bisphenol A: a physiologically based pharmacokinetic approach. Toxicol Sci.,85:823-38.

4. Koenig,T., Menze,B.H., Kirchner,M., Monigatti ,F., Parker,K.C., Patterson,T., Steen,J.J., Hamprecht,F.A., Steen,H.(2008): Robust Prediction of the MASCOT Score for an Improved Quality Assessment in Mass Spectrometric Proteomics. J. Proteome Res, 7:3708-3717.

5. Mount, D.M., Bioinformatics: Sequence and Genome Analysis, 2nd ed., Cold SpringHarbor Laboratory Press: Cold Spring Harbor, NY.

6. Oyedeji,K.O., Bolarinwa,A.F., Hamzat,M.A.(2004):Effect of Palm Wine on Reproductive Functions in Male Albino Rats. Res J Bio Sci, 7: 340-344.

7. Benkert,P., Tosatto,S.C.E., Schomburg,D.(2008):QMEAN: A Comprehensive Scoring Functionfor Model Quality Assessment. Prot Stru Fun Bioinfor,71: 261-277.

8. Benkert,P., Schwede,T., Tosatto SCE.(2009):QMEANclust: estimation of protein model quality by combining a composite scoring function with structural density information. BMC. Struct Biol,9:1-17.

9. Xu,X-H et al.,(2010): Perinatal Exposure to Bisphenol-A Impairs Spatial Memory through Upregulation of Neurexin1 and Neuroligin3 Expression in Male Mouse Brain J Environ. Toxicol. Chem.29, 177.

10. Wessam mohammad Abdel-wahab.(2014): Thymoquine Attenuates Toxicity And Oxidative Stress Induced By Bisphenol A In Liver Of Male, Pak.biol. sci,7(11);1152-1160.

11. Larkin,M.A. Blackshields, G., Brown,N.P.,Chenna,R., Mc Gettigan,P.A., McWilliam,H., Valentin,F., Wallace,I.M., Wilm,A., Lopez,R., Thompson,J.D., Gibson,T.J., HigginsD.G.(2007):Clustal W and Clustal X version 2.0. Bioinformatics, 23: 2947-2948.

12. Adham,I.M., Burkhardt,E., and Benahmed,M. (1993): Cloning of a cDNA for a novel insulin-like peptide of the testicular Leydig cells. J. Biol. Chem, 268:26668-26672.

13. Burkhardt,E., Adham,I.M.and Brosig,B. (1994)Structural organization of the porcine and human genes coding for a Leydig cell-specific insulinlike peptide (LEY I-L) and chromosomal localization of the human gene (INSL3). Genomics, 20,:13-19.

14. Nef, S. and Parada,L.F.( 1999):Cryptorchidism in mice mutant for Insl3. Nat Genet, 22:295-299.

15. Zimmermann,S., Steding,G., Emmen,J.M., Brinkmann,A.O., Nayernia,K., Holstein,A.F.and Engel,W.(1999): Targeted disruption of the Insl3 gene causes bilateral cryptorchidism. Mol Endocrinol, 13:681-691.

16. Anand-Ivell,R.J.K., Wohlgemuth., Haren,M.T., Hope,.J., Hatzinikola, G., Wittert,G., IvellR.(2006) Peripheral INSL3 concentrations decline with age in a large population of Australian men. Int J Androl 29:618-626.

17. Ferlin, A., Garolla, A., Rigon, F., Rasi Caldogno, L., Lenzi, A., Foresta .C.(2006):Changes in serum insulinlike factor 3 during normal male puberty. J Clin Endocrinol Metab 91:3426-3431.

18. Lague,E and Tremblay,J.J.(2008): Antagonistic effects of testosterone and the endocrine disruptor mono-(2ethylhexyl) phthalate on INSL3 transcription in Leydig cells. Endocrinology, 149:4688-4694

19. Turner, T.T., Ewing,L.L., Jones,C.E., Howards,S.S., Zegeye,B.(1985): Androgens in male rat reproductive tract fluids: hypophysectomy and steroid replacement. Am J Physiol, 248:E274-E280.

20. Willers,I.M., Isidoro,A., Ortega,A.D., Fernandez,P., Cuezva,J.M.(2010): selective inhibition of beta f1-atp ase mrna translation in human tumours, biochem J,426:319-326.

21. Izquierdo, J.M. and Cuezva, J.M.(1997): Control of the translational efficiency of beta-F1-ATPase mRNA depends on the regulation of a protein that binds the 3' untranslated region of the mRNA. Mol Cell Biol, Sep;17(9):5255-5268. 
22. Chi,S.L., Wahl,M.L. MoweryY.M., Shan,S., Mukhopadyay,S., Hildebrand,S.C., Kenan,D.J., Lipes, B.D., Johnson,C.E., $\quad$ Maurisch,M.F., $\quad$ Capaldi,R.A., $\quad$ Dewhirst,M.W., $\quad$ Pizzo,S.V.(2007):Cancer $\quad$ Res. May $15 ; 67(10): 4716-24$.

23. Hemocentro \& University of São Paulo. (2011):Ribeirão Preto Medical School, Ribeirão Preto, Brazil Indian J Med Res 134, October , pp 532-537

24. Hebbel,R.P.(1997): Adhesive interactions of sickle erythrocytes with endothelium. J Clin Invest,100 (11 Suppl): S83-6.

25. Platt,O.S.(2000): Sickle cell anemia as an inflammatory disease. J Clin Invest, 106:337-8.

26. Hebbel, R.P, (2008):Adhesion of sickle red cells to endothelium: Myths and future directions. Transfus Clin Biol, $15: 14-8$.

27. Chiang,E.Y. and Frenette,P.S.(2005): Sickle cell vaso-occlusion. Hematol Oncol Clin North Am, 9 :771-94.

28. Nemer, W EI., Colin,Y., C Le Van Kim,C. (2010) :Role of Lu/BCAM glycoproteins in red cell diseases. Transfus Clin Biol, 17:143-7.

29. Rivera,A., Jarolim,P., Brugnara.C.(2002): Modulation of Gardos channel activity by cytokines in sickle erythrocytes. Blood,99 : 357-603.

30. Merciris,P., Giraud,F.(2001): How do sickle cells become dehydrated? Hematol J,2 :200-5. 31.

31. G.J., Kato, M.T.and Gladwin, M.H.( 2007): Steinberg. Deconstructing sickle cell disease: reappraisal of the role of hemolysis in the development of clinical subphenotypes. Blood Rev , $21: 37-47$ 